\section{Malnutrition in prisoners admitted to a medical ward in a developing community}

Joel O Babashola Olubodun, Alfred E A Jaiyesimi, E A Fakoya, Olayinka A Olasode

Department of Medicine, Ogun State University Teaching Hospital, PMB 2001 Shagamu, Nigeria Joel O Babashola Olubodun, FMCP(NIGERIA), physician Alfred E A Jaiyesimi, FMCP(NIGERIA), physician E A Fakoya, MD, physician Olayinka A Olasode, MB, registrar

Correspondence to: Dr J O B Olubodun, Ward 4, Freeman Hospital, High Heaton, Newcastle upon Tyne NE7 7DN

BMF 1991;303:693-4 our medical ward over one year.

\section{Subjects, methods, and results}

Malnutrition is common among prisoners of war. ${ }^{1}$ Observations in our hospital suggested that malnutrition might also be alarmingly common and severe among prisoners in the developing world. ${ }^{2}$ This paper describes the nutritional state of prisoners admitted to

Prisoners admitted to our medical ward over one year were examined for malnutrition. Using the criteria of Baker et al ${ }^{3}$ we based the diagnosis on subjective global assessment - that is, including weakness, weight loss, skin and hair changes, muscle wasting, oedema, and skin infections (tinea versicolor and scabies)-and objective measurements-including weight, height, weight as percentage of standard for height, serum albumin concentration, and packed cell volume. Subjects less than $60 \%$ of standard weight were considered to be severely malnourished and those $60-90 \%$ of standard weight moderately malnourished. A serum albumin concentration of $25-30 \mathrm{~g} / \mathrm{l}$ was regarded as moderately low and a concentration $<25 \mathrm{~g} / \mathrm{l}$ as severely low. Sputum was examined for Mycobacterium tuberculosis. Appropriate dietary and antituberculous regimens were instituted and the nutritional variables re-evaluated four weeks later.

Ten male prisoners were admitted during the year, of whom one died of severe diarrhoea shortly after admission and was therefore excluded. Of the remainder, six were malnourished and three had other diseases. The history in all cases indicated undernutrition and overcrowding in prison. There was lack of financial support and reluctance of relations to identify with the prisoners. The six with malnutrition looked depressed and apathetic. Of these, four had pedal oedema, all had hair changes, and four skin changes and infections. In addition, five had pulmonary tuberculosis, two peripheral neuropathy, and one chronic myeloid leukaemia.

The table gives the findings in all nine cases. Three of the malnourished patients had severe and three moderate malnutrition. Serum albumin concentration was estimated in three of the malnourished patients on admission and was severely low in two. After four weeks of adequate nutrition concentrations were normal in three, low or moderately low in one, severely low in one, and not estimated in one. Concentrations were within the lower limit of normal in the two non-malnourished patients in whom they were measured.

All patients had a low packed cell volume on admission (mean 0.27 (SD 0.07)), and this was particularly so in the malnourished group. The mean durations of detention were $19 \cdot 3$ (SD 13.7) and $7 \cdot 2(4 \cdot 4)$ months respectively in the malnourished and nonmalnourished patients. Durations of detention did not correlate with changes in percentage of standard weight. No patient had significant proteinuria, and none showed features of malabsorption.

Within four weeks of treatment the malnourished patients showed a satisfactory response as evidenced by weight gain and increased packed cell volume.

\section{Comment}

These results confirm that advanced malnutrition may be common among prisoners in the developing world. With decreased energy intake energy is derived from body fat and muscle catabolism. The features include progressive weight loss; thirst; craving for food; weakness; lax, pale, and dry skin with pigmented patches and loss of turgor; thinned hair; and pedal oedema (famine oedema). There is increased risk of infections, particularly pneumonia, tuberculosis, and gastrointestinal infections, probably due to globulin blunting.

In this series malnutrition seemed to be due mostly to underfeeding and possibly to reduced appetite. The acquisition of tuberculosis may have been due to the overcrowding in prison and subsequent predisposition to malnutrition. On the other hand, a poor diet also aids the spread of tuberculosis among inmates. Thiamine deficiency and cyanide poisoning may also occur in prisoners fed predominantly rice and cassava diets.

The degree of malnutrition and infection observed among these prisoners is much higher than in adults outside prison and contrasts with the picture in parts of the developed world where prisoners receive better treatment.

The marginal change in serum albumin concentration recorded after four weeks of nutritional rehabilitation might indicate that it takes longer to return to normal in prisoners.

This study highlights the grossly inadequate health care given to prisoners in the developing world and draws attention to the need for nutritional and health care surveys in prisons. 5 Prisons have a duty to look after their inmates' health. "Destructive imprisonment" is costly to the prisoner, his relations, and the nation, both financially and in terms of human resources.

Burges RC. Deficiency disease in prisoners of war at Changi, Singapore. Lance 1956;ii:411-8.

Clinical and laboratory details of patients, durations of detention, and diagnoses

\begin{tabular}{|c|c|c|c|c|c|c|c|c|c|}
\hline $\begin{array}{l}\text { Case } \\
\text { No }\end{array}$ & $\begin{array}{c}\text { Age } \\
\text { (years) }\end{array}$ & $\begin{array}{l}\text { Height } \\
(\mathrm{cm})\end{array}$ & $\begin{array}{c}\text { Weight } \\
(\mathrm{kg}) \dagger\end{array}$ & $\begin{array}{c}\text { Standard } \\
\text { weight }(\mathrm{kg})\end{array}$ & $\begin{array}{l}\text { Weight as \% } \\
\text { of standard } \dagger\end{array}$ & $\begin{array}{l}\text { Packed cell } \\
\text { volume }\end{array}$ & $\underset{(\mathrm{g} / \mathrm{l}) \dagger}{\operatorname{Serum} \text { albumin }}$ & $\begin{array}{l}\text { Duration of } \\
\text { detention } \\
\text { (months) }\end{array}$ & Diagnosis \\
\hline 1 & 29 & 174 & $46(54)$ & $68 \cdot 6$ & $67 \cdot 1(78 \cdot 7)$ & $0.26(0.40)$ & $25(34)$ & 36 & $\begin{array}{l}\text { Malnutrition, pulmonary tuberculosis, tinea } \\
\text { versicolor }\end{array}$ \\
\hline 2 & 25 & 172 & $36(47)$ & $67 \cdot 0$ & $53 \cdot 7(70 \cdot 1)$ & $0.16(0.25)$ & $24(22)$ & 12 & $\begin{array}{l}\text { Malnutrition, pulmonary tuberculosis, tinea } \\
\text { versicolor, scabies }\end{array}$ \\
\hline $3^{\star}$ & 25 & 170 & 63 & $65 \cdot 0$ & $96 \cdot 9$ & $0 \cdot 30(0 \cdot 33)$ & 32 & 1 & Hepatic abscess \\
\hline 4 & 26 & 173 & $41(44)$ & $67 \cdot 8$ & $60 \cdot 5(64 \cdot 9)$ & NE $(0.36)$ & $\mathrm{NE}(30)$ & 36 & $\begin{array}{l}\text { Malnutrition, pulmonary tuberculosis, tinea } \\
\text { versicolor, scabies }\end{array}$ \\
\hline $5 \star$ & 35 & 169 & $63 \cdot 5$ & $64 \cdot 0$ & $99 \cdot 2$ & $0 \cdot 37$ & 32 & $10 \cdot 5$ & Peptic ulcer disease \\
\hline 6 & 29 & 168 & $33(55)$ & $62 \cdot 9$ & $52 \cdot 5(87 \cdot 4)$ & $0 \cdot 20(0.29)$ & NE (39) & 6 & Malnutrition, chronic myeloid leukaemia \\
\hline 7 & 22 & 170 & $25(41)$ & $65 \cdot 0$ & $38 \cdot 5(63 \cdot 1)$ & NE $(0.33)$ & $\mathrm{NE}(37)$ & 24 & $\begin{array}{l}\text { Malnutrition, pulmonary tuberculosis, tinea } \\
\text { versicolor }\end{array}$ \\
\hline $8 \star$ & 34 & 167 & 62 & $62 \cdot 1$ & $99 \cdot 8$ & $0 \cdot 35$ & $\mathrm{NE}$ & 10 & Bleeding peptic ulcer \\
\hline 9 & 35 & 172 & $41(45)$ & $67 \cdot 0$ & $61 \cdot 2(67 \cdot 2)$ & $0.24(0.34)$ & $22(\mathrm{NE})$ & $1 \cdot 5$ & Malnutrition, pulmonary tuberculosis \\
\hline
\end{tabular}

^Patient with no clinical features of malnutrition. †Figures in parentheses are estimations one month later in malnourished patients. NE-Not estimated. 


\title{
Lipoprotein (a) concentrations in postmenopausal women taking norethisterone
}

\author{
E Farish, H A Rolton, J F Barnes, D M Hart
}

\section{Department of}

Biochemistry, Stobhill

General Hospital, Glasgow G21 3UW

E Farish, PHD, principal

biochemist

H A Rolton, PHD, senior

biochemist

J F Barnes, BSC, research

assistant

Department of Obstetrics and Gynaecology, Stobhill General Hospital, Glasgow D M Hart, MD, consultant gynaecologist

Correspondence and requests for reprints to: Dr Farish.

BMY 1991;303:694
Hormone replacement therapy is effective in treating menopausal symptoms and preventing osteoporosis. Regimens usually consist of oestrogen or an oestrogenprogestogen mixture. Postmenopausal oestrogen substantially reduces the risk of death from cardiovascular disease, due in part to lipoprotein changes, particularly an increase in high density lipoprotein concentration. When oestrogen is contraindicated a progestogen only regimen may be used. The androgenic progestogen norethisterone, which can substantially improve climacteric symptoms and decrease bone loss, is commonly prescribed.' Norethisterone, however, adversely affects lipoprotein metabolism, causing a pronounced decrease in high density lipoprotein concentration. ${ }^{2}$

There has been an upsurge of interest in lipoprotein (a), high concentrations of which are associated with atherosclerosis. A growing body of evidence suggests that lipoprotein (a) is an important independent risk factor for cardiovascular disease with possibly greater predictive potential than the other lipoprotein risk markers. Most hypolipidaemic agents currently in use have little or no effect on lipoprotein (a). ${ }^{3}$ Oestrogen reportedly has no effect on lipoprotein (a). ${ }^{4}$ In contrast, the anabolic steroid stanozolol, used in postmenopausal osteoporosis, substantially decreases lipoprotein (a) concentrations. ${ }^{5}$ Stanozolol has adverse effects, similar to those of norethisterone, on other lipoproteins. To our knowledge the effects of progestogens on lipoprotein (a) have not been studied. We have therefore carried out a small pilot study to see whether concentrations are affected by norethisterone.

\section{Patients, methods, and results}

We studied nine women who had detectable lipoprotein (a) concentrations $(>50 \mathrm{mg} / \mathrm{l})$. Their average age was 50 . Five had had bilateral oophorectomy at least two months before starting treatment. The other four had had a natural menopause, as judged by established amenorrhoea and postmenopausal gonadotrophin values. None had received any hormonal treatment before recruitment. All suffered from menopausal symptoms and were considered unsuitable for oestrogen treatment because of a history of thromboembolic disease. They were treated with norethisterone (Primolut N) $5 \mathrm{mg}$ twice daily.

Fasting blood samples were obtained before treatment and after two months of treatment. Lipoprotein (a) was measured by an enzyme linked immunosorbent assay (ELISA; Immuno Ltd). Values at two months were compared with baseline by using Wilcoxon's matched pairs signed ranks test.

Pretreatment lipoprotein (a) concentrations ranged from 90 to $800 \mathrm{mg} / \mathrm{l}$ (median $300 \mathrm{mg} / \mathrm{l}$ ). After two months the median concentration had fallen by $47 \%$ to 160 (range 60 to 220$) \mathrm{mg} / \mathrm{l}(\mathrm{p}<0.01)$. A decrease was recorded in every subject, the largest falls occurring in

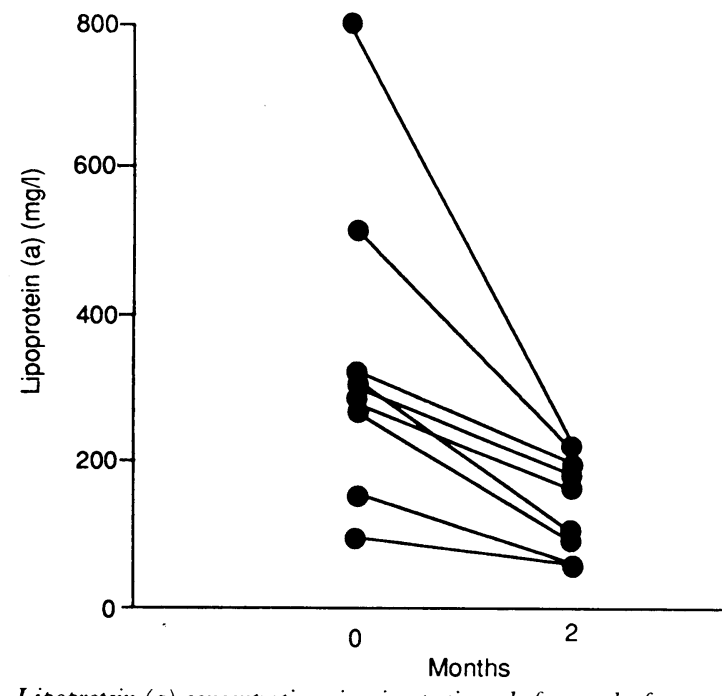

Lipoprotein (a) concentrations in nine patients before and after two months of norethisterone

the two patients with the highest pretreatment values (figure).

\section{Comment}

These findings may be important in relation to hormone replacement therapy. Although it has not as yet been shown that lowering lipoprotein (a) concentrations reduces the risk of cardiovascular disease, by analogy with the results of other risk factor studies it seems likely that such a change will be beneficial. Previous work on lipoproteins has indicated that norethisterone may be unsuitable for long term prophylaxis against osteoporosis.' Its effect on lipoprotein (a) concentrations, however, might, at least to some extent, offset its adverse effects on other lipoprotein risk factors.

Women who have not had hysterectomy who use postmenopausal oestrogens also receive a progestogen to protect them against endometrial cancer. Norethisterone is commonly used in combined preparations and there is concern that its effect on high density lipoproteins could partially negate the beneficial effects of oestrogen on the cardiovascular system. Our results suggest that the use of androgenic progestogens such as norethisterone may not be as deleterious as was previously feared. We suggest that in future hormone replacement studies lipoprotein (a) should be added to the lipoprotein risk markers currently monitored.

I Abdalla HI, Hart DM, Lindsay R, Leggate I, Hooke A. Prevention of bone mineral loss in postmenopausal women by norethisterone. Obstet Gynecol mineral loss in

2 Farish E, Fletcher CD, Hart DM, Dagen MM, Parkin DE. Lipoprotein and apoprotein levels in postmenopausal women during treatment with norethisterone. Clin Chim Acta 1986;159:147-51.

3 MBewu AD, Durrington PN. Lipoprotein (a): structure, properties and possible involvement in thrombogenesis and atherogenesis. Atherosclerosis $1990 ; 85: 1-14$

4 Albers JJ, Cazbano VG, Warnick GR, Hazzard WR. LP(a) lipoprotein: relationship to sinking pre- $\beta$ lipoprotein hyperlipoproteinemia, and apolipoprotein B. Metabolism 1975;24:1047-54

5 Albers JJ, Taggart HMcA, Applebaum-Bowden D, Haffner S, Chestnut CH, Hazzard WR. Reduction of lecithin-cholesterol acvl transferase, apolipoprotein B and the LP(a) lipoproteins with the anabolic steroid stanozolol. Biochim Biophys Acta 1984;795:293-6.

(Accepted 4 fuly 1991) 